\title{
THE BIOSYNTHESIS OF THE FATTY ACIDS OF THE PLASMA OF MAN. I. THE FORMATION OF CERTAIN CHROMATOGRAPHICALLY SEPARATED HIGHER FATTY ACIDS OF THE MAJOR LIPIDE COMPLEXES FROM ACETATE-1-C14 1
}

\author{
By S. R. LIPSKY, A. HAAVIK, C. L. HOPPER, AND R. W. MCDIVITT wITH THE \\ TECHNICAL ASSISTANCE OF BARBARA M. MOSSBERG
}

(From the Department of Medicine, Yale University, New Haven, Conn.)

(Submitted for publication July 2, 1956; accepted October 17, 1956)

One of the outstanding difficulties precluding the use of radioactive tracers for a detailed study of the dynamics of lipide metabolism in man has been the lack of adequate micromethods for the isolation and identification of the major lipide complexes present in the plasma and the individual fatty acids associated with these groups. In recent years, with the advent of new chromatographic procedures, two significant achievements have occurred in this sphere. By the use of silicic acid columns, Borgström $(1,2)$ in 1952 and Fillerup and Mead (3) in 1953 separated lipide extracts into sterol ester, triglyceride, free fatty acid and phospholipide fractions. Crombie, Comber, and Boatman (4) extended the reverse phase partition chromatographic technique of Howard and Martin (5), and while encountering considerable overlapping of zones, demonstrated the separation of milligram quantities of certain common saturated and unsaturated fatty acids contained in natural mixtures.

The present investigation was undertaken in an effort to combine and modify these methods in order to determine: (a) the nature and quantity of the specific higher saturated and unsaturated fatty acids that form ester linkages with the lipide complexes of the plasma of man and (b) the rates of synthesis of these acids following the administration of acetate-1-C 14 .

\section{METHODS AND MATERIALS}

Part 1. The separation of the total lipide extract of the plasma into the total fatty acids of the sterol esters, the triglycerides and the phospholipides

a) Extraction. Four patients with limited life expectancies due to carcinoma of the lung without evidence of

1 This work was supported by a grant (AT(30-1)1846) from the Atomic Energy Commission. Additional aid was obtained from institutional grants from the Fluid Research Fund of Yale University and the American Cancer Society. metastases were selected for study. All were considered to be in a good nutritional state and clinically free from gross metabolic disturbances. The subjects were maintained on normal hospital diets during the course of the investigation. Two hundred microcuries of acetate-1-C $\mathrm{C}^{14}$ (specific activity $1.0 \mathrm{mc}$. per $\mathrm{mM}$ ) were dissolved in a convenient volume of tap water and administered orally to all patients in the postabsorptive state on the morning of the experiment. Serial blood samples of approximately $60 \mathrm{ml}$. were taken in heparinized syringes beginning one hour after the administration of acetate and continued at intervals for 96 hours. Thirty-five $\mathrm{ml}$. of plasma was then removed after centrifugation and rapidly blown into a one-liter Erlenmeyer flask containing $525 \mathrm{ml}$. of a $4: 1$ mixture of dimethoxymethane: methanol (6). At this point in some preliminary experiments, individual carbon-14 or tritium labelled lipides of known specific activity ${ }^{2}$ were dissolved in one $\mathrm{ml}$. of petroleum ether and added to the flask. The mixture was allowed to boil momentarily by cautiously rotating the flask under a hot water tap. After cooling for fifteen minutes, with frequent swirling, the mixture was filtered through an $18.5 \mathrm{~cm}$. Whatman No. 1 filter paper into a one-liter round bottom flask with a side arm. The precipitate was washed twice with an additional $30 \mathrm{ml}$. of the dimethoxymethane:methanol mixture and the washings added to the lipide extract contained in the flask. The flask was placed on a constant temperature water bath maintained at $50^{\circ} \mathrm{C}$ and the clear yellow solution was concentrated to a small volume under reduced pressure. Throughout this procedure oxygenfree nitrogen was allowed to flow onto the surface of the liquid via the side arm. The capillary tip by which the nitrogen was delivered was not placed below the surface of the liquid since this tended to induce excessive foaming as evaporation proceeded. Forty $\mathrm{ml}$. of warmed

2 The labelled radiochemicals were obtained from the following sources: a) Triolein-courtesy of Dr. David Kritchevsky, American Cyanamid Co., Pearl River, N. Y. (7). b) Tripalmitin, tristearin, palmitic acid, and stearic acid-Isotopes Specialties Co., Burbank, Calif. c) Sterol Ester-prepared according to the procedure of Borgström (8). d) Phospholipides-prepared biosynthetically following the administration of acetate- $1-C^{14}$ to a subject. The phospholipides of the lipide extract of the plasma were obtained by precipitation with cold acetone and ethanolic $\mathrm{MgCl}_{2}$ followed by repeated washings. 


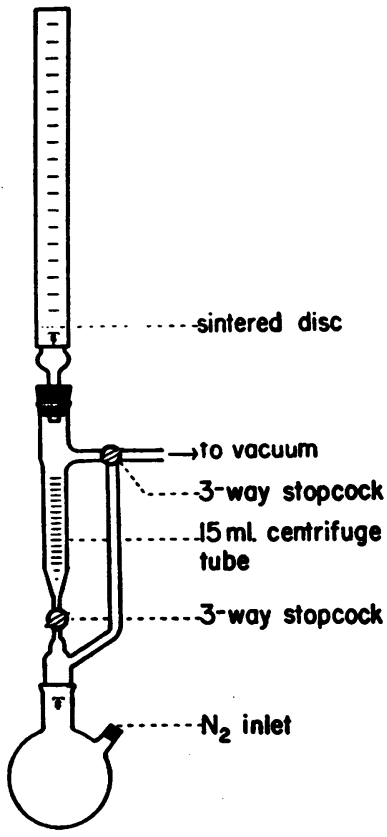

Fig. 1. Silicic Acid Chromatographic System for the Separation of the Major Lipide Complexes of the Plasma

Chromatographic tube 400 by $19 \mathrm{~mm}$. The lower 3-way stopcock has an outlet to the atmosphere and is attached to a standard $24 / 40$ ground glass joint.

petroleum ether (b.p. $30^{\circ}$ to $60^{\circ} \mathrm{C}$ ) was then added to the flask, the flask was stoppered with a ground glass stopper and shaken vigorously for two minutes. The supernatant petroleum ether layer was transferred to a $300-\mathrm{ml}$. round bottom flask with a side arm by means of a simple thin glass tube siphon device attached to water suction. The petroleum ether extraction was then repeated four more times. It was found that for quantitative recoveries, this technique of transfer was superior in all respects to that employing the use of separatory funnels.

The petroleum ether extracts were combined and the solvent was evaporated off under nitrogen at reduced pressure as described. The total lipide extract was then stored under nitrogen at $-4^{\circ} \mathrm{C}$ until it was to be chromatographed.

b) Chromatographic separation on silicic acid columns. A snugly fitting piece of coarse filter paper was placed on top of the sintered disc at the bottom of the chromatography tube depicted in Figure 1. Twenty grams of silicic acid (100 mesh, Mallinckrodt) was thoroughly mixed with 4 grams of "Hyflo-Supercel" (Johns-Manville) and added to the tube. This ratio of filter aid to absorbent was found to provide excellent resolution with an adequate flow rate. The mixture was then packed by tapping the tube gently on a firm surface. Another filter paper disc was placed on top of the column and the column was washed with 70-ml. portions of absolute methanol, acetone, anhydrous peroxide-free ether and petro- leum ether (3). The lipide extract to be chromatographed was dissolved in four to eight $\mathrm{ml}$. of warmed 1 per cent ether in petroleum ether and quantitatively added dropwise to the top of the column. The sides of the column were then washed down with an additional five to ten ml. of solvent. In preliminary experiments (Table I), elution was carried out with the solvent systems recommended by Fillerup and Mead $(3,9)$. Since it was noted that some of the phospholipide fraction was eluted prematurely by solvent systems containing moderate concentrations of diethyl ether, the following technique was adopted to separate the sterol ester, triglyceride and phospholipide components of the plasma. Following the concentration of the total lipide extract prior to chromatographic separation, this material was taken up in a small volume of petroleum ether and quantitatively transferred to a heavy walled $40-\mathrm{ml}$. centrifuge tube. The final volume was reduced to about two to four $\mathrm{ml}$. by evaporating off the excess of petroleum ether under a stream of nitrogen. Thirty ml. of cold acetone and ten drops of saturated $\mathrm{MgCl}_{2}$ in ethanol were then added to the tube to precipitate the phospholipides. The tube was agitated and then placed in a refrigerator and allowed to stand overnight. Following centrifugation, the supernatant which contained the entire lipide extract with the exception of the phospholipides was siphoned off into a 200 -ml. round bottom flask with a side arm. The precipitated phospholipides were washed two to three times with 30-ml. portions of cold acetone. After repeat centrifugation the acetone supernatants were then combined. Recoveries for phospholipides by this technique ranged from 97 to 102 per cent. Control cross contamination experiments performed by the addition of carbon14 labelled sterol, fatty acid, triglyceride, and biosynthetically prepared radioactive phospholipide usually demonstrated less than 1 per cent contamination of the phospholipide precipitate by non-phospholipide constituents. Similar results were obtained when the acetone supernatants were assayed for contamination by the phospholipides. These findings are in accord with the observations of Borgström (1) employing the same technique.

The combined acetone supernatants were evaporated to dryness under nitrogen at reduced pressure. The residue was taken up in two to five ml. of warmed 1 per cent ether in petroleum ether and applied to the top of the silicic acid column as described. The sterol esters were eluted with $300 \mathrm{ml}$. of 1 per cent ether in petroleum ether; the triglycerides with $350 \mathrm{ml}$. of 3 per cent ether in petroleum ether. An elution rate of approximately 150 ml. per hour was maintained in all experiments by means of a "Manostat" attached to a vacuum pump. After separation the eluates were evaporated down to dryness as previously described, taken up in petroleum ether and then quantitatively transferred to a $100-\mathrm{ml}$. round bottom flask with a side arm. The phospholipide precipitate was also dissolved in a small volume of warm petroleum ether and transferred in a similar fashion.

c) Saponification. To each flask were added $20 \mathrm{ml}$. 
TABLE I

Distribution of added radioactivity appearing in the oarious chromatographed fractions of plasma lipides in order of elution

\begin{tabular}{|c|c|c|c|c|c|c|c|c|}
\hline $\begin{array}{l}\text { Solvent } \\
\text { system }\end{array}$ & $\begin{array}{l}\text { Radioactive } \\
\text { tracer* }\end{array}$ & $\begin{array}{l}\text { Sterol } \\
\text { esters } \\
300 \text { ml. } \\
1 \% \text { ether } \\
\text { in pet. } \\
\text { ether }\end{array}$ & $\begin{array}{l}\text { Triglycer- } \\
\text { ides } \\
300 \mathrm{ml} \text {. } \\
3 \% \text { ether } \\
\text { in pet. } \\
\text { ether }\end{array}$ & $\begin{array}{l}\text { Free fatty } \\
\text { acids } \\
225 \mathrm{ml} . \\
10 \% \text { ether } \\
\text { in pet. } \\
\text { ether }\end{array}$ & $\begin{array}{l}\text { Sterol } \\
225 \mathrm{ml} \text {. } \\
50 \% \text { ether } \\
\text { in pet. } \\
\text { ether }\end{array}$ & $\begin{array}{c}\text { Combined } \\
\text { fraction } \\
\text { Free fatty } \\
\text { acids + Sterol } \\
\text { eluted with } \\
300 \mathrm{ml} \\
50 \% \text { ether } \\
\text { in pet. ether }\end{array}$ & $\begin{array}{l}\text { Phospho- } \\
\text { lipides } \\
225 \mathrm{ml} \\
25 \% \text { meth- } \\
\text { anol in } \\
\text { ether }\end{array}$ & $\begin{array}{l}\text { Recovery } \\
\text { of radio- } \\
\text { activity } \\
\text { in specific } \\
\text { fraction } \\
\text { per cent }\end{array}$ \\
\hline \multirow[t]{6}{*}{ A } & Triolein-H ${ }^{3}$ & 19 & 2,995 & 79 & 18 & & 3 & 96 \\
\hline & $\begin{array}{c}\text { Tripalmitin-1-C } \\
15,140\end{array}$ & 36 & 14,750 & 177 & 34 & & 29 & 97 \\
\hline & Stearic acid-1-C 14 & 30 & 51 & 6,054 & 5,911 & & 71 & 46 \\
\hline & $\underset{11,017}{\text { Palmitic acid-1-C14 }}$ & 37 & 43 & 5,105 & 5,417 & & 84 & 46 \\
\hline & $\begin{array}{l}\text { Cholesterol-4-C14 } \\
20,980\end{array}$ & 24 & 97 & 14,070 & 5,890 & & 228 & 28 \\
\hline & $\begin{array}{l}\text { Cholesterol-4-C }{ }^{14} \\
20,797\end{array}$ & 36 & 106 & 13,895 & 6,057 & & 185 & 24 \\
\hline \multirow[t]{5}{*}{ B } & Sterol Ester-C14 $†$ & 8,508 & 143 & & & 24 & 47 & 98 \\
\hline & $\begin{array}{l}\text { Tripalmitin-1-C14 } \\
13,955\end{array}$ & 52 & 13,987 & & & 98 & 26 & 100 \\
\hline & $\begin{array}{l}\text { Stearic acid-1-C14 } \\
11,737\end{array}$ & 26 & 412 & & & 11,521 & 158 & 98 \\
\hline & $\begin{array}{l}\text { Cholesterol-4-C14 } \\
16,336\end{array}$ & 56 & 145 & & & 15,636 & 238 & 95 \\
\hline & $\begin{array}{l}\text { Phospholipide-C14 } \uparrow \\
\quad 1,991\end{array}$ & 28 & 83 & & & 170 & 1,715 & 86 \\
\hline
\end{tabular}

* Counts per minute added to the column.

$\dagger$ Typical examples of the separation of certain lipide fractions by chromatography with silicic acid using various solvent systems.

of 95 per cent ethanol and $0.7 \mathrm{ml}$. of 90 per cent aqueous $\mathrm{KOH}$. A small Soxhlet water condenser was attached to the top of each flask, a stream of nitrogen introduced via the side arm, and the material refluxed for $90 \mathrm{~min}$ utes in a boiling water bath. During the procedure, evaporation of approximately 50 to 75 per cent of the ethanol occurred. The samples were then removed from the bath and allowed to cool. Five $\mathrm{ml}$. of $\mathrm{H}_{2} \mathrm{O}$ and twenty $\mathrm{ml}$. of 95 per cent ethanol were added to each flask. The mixture was extracted three times with petroleum ether. The petroleum ether washings were combined and washed once with alcoholic KOH. This ethanol wash was added to the original aqueous material remaining in the flask and the petroleum ether extracts were then discarded. The mixture was made acid to phenophthalein with $6 \mathrm{~N} \mathrm{H}_{2} \mathrm{SO}_{4}$. Ten to twenty $\mathrm{ml}$. of $\mathrm{H}_{2} \mathrm{O}$ were added and the mixture was then extracted three times with $20-\mathrm{ml}$. aliquots of petroleum ether. The combined petroleum ether extracts were washed once with 5 per cent sodium bicarbonate, three times with distilled water, and then dried over anhydrous sodium sulfate. The solvent was evaporated off under nitrogen at reduced pressure and the fatty acid residue was transferred to a $25-\mathrm{ml}$. volumetric flask and brought up to volume with petroleum ether.

d) Assay. Portions of these samples were then taken in duplicate, placed in small test tubes and the solvent blown off with a stream of nitrogen. The residue was taken up in $2 \mathrm{ml}$. of 65 per cent acetone in water $(\mathrm{v} / \mathrm{v})$ and two drops of bromthymol blue added. The total fatty acids of each class of lipides was then determined by titrating the sample under nitrogen against $0.005 \mathrm{~N} \mathrm{KOH}$ in a microburette calibrated in $0.001 \mathrm{ml}$. In experiments where radioactive tracers were employed, another sample was removed from the volumetric flask, transferred to a 30-ml. counting vial (Kimble K-10 "Opticlear") and evaporated to dryness. To this vial was added $15 \mathrm{ml}$. of toluene containing 0.4 per cent of the phosphor, 2,5 diphenyloxazole and 0.005 per cent of the wave length shifter 1,4-di-[2-(5-phenyloxazolyl)]-benzene (10). The radioactivity contained in the vial was determined in a dual channel liquid scintillation counter ${ }^{3}$ which had an efficiency of 75 per cent for carbon-14 (with an 11:1 energy acceptance window and a background of $30 \mathrm{cpm}$.) and 22 per cent for tritium. All counts were corrected for background and counted to a standard error of 2 per cent.

Part II. The isolation of individual higher saturated and unsaturated fatty acids commonly found in ester linkage with the major lipide complexes

a) Preparation of kieselguhr columns. Five pounds of "Hyflo Supercel" (Johns-Manville) were thoroughly

\footnotetext{
${ }^{3}$ Technical Measurements Corporation, New Haven,
} Conn. 


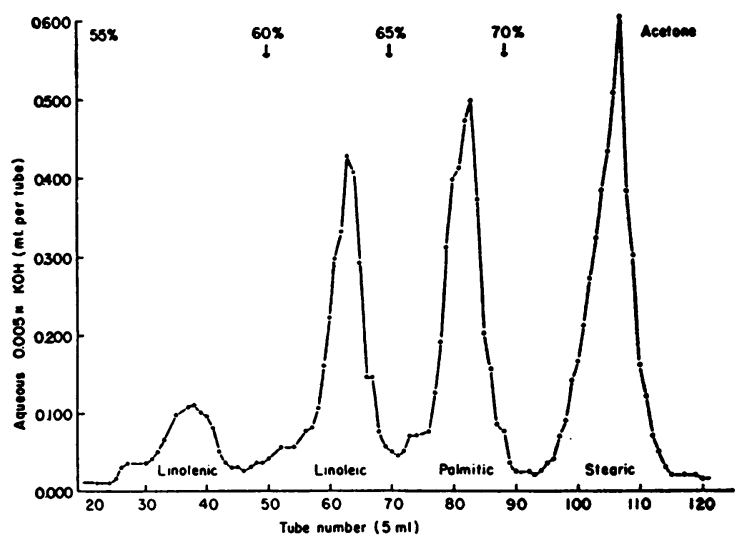

Fig. 2. The Resolution of a Mixture of Linolenic, Linoleic, Palmitic, and Stearic Acids

The arrows represent the points where the aqueous acetone solvent systems were changed. Column, 130 by $1.0 \mathrm{~cm}$.

mixed with several gallons of distilled water in a high wide-mouth glass container. The mixture was allowed to settle for ten minutes, after which time the fine particles that float were removed by aspiration. The washing process was repeated three to four more times. The Celite was then transferred to large glass trays, excess water decanted, and the tray placed in a drying oven maintained at $110^{\circ}$ for 24 hours. The material should be thoroughly dry before further processing. The Celite was then transferred to large evaporating dishes and placed in a large vacuum desiccator at the bottom of which was $20 \mathrm{ml}$. of dichlorodimethylsilane in a widemouth container. The desiccator was partially evacuated and the silane vapors allowed to remain in contact with the Celite for four hours. The Celite was then removed and placed in a 3-liter beaker filled with water. The mixture was vigorously stirred and the particles that did not float were discarded. The coated Celite was transferred to a large Buchner funnel and washed several times with water and then methanol until the washings appeared neutral when tested with $\mathrm{pH}$ paper. The material was then thoroughly dried in an oven maintained at $80^{\circ} \mathrm{C}$.

The most satisfactory separation of certain mixtures of the higher saturated and unsaturated fatty acids was obtained by using a jacketed column $1 \mathrm{~cm}$. in diameter and $130 \mathrm{~cm}$. in height equipped with a small reservoir at the top and an "Ultramax" valve at the bottom. For a column of this size, 48 grams of coated Celite and 34.8 grams of Standard White Oil No. 15 USP 4 were placed in separate beakers. One hundred $\mathrm{ml}$. of anhydrous peroxide-free ether was added with stirring to the mineral oil. The Celite was then added. The beaker was placed in a warm bath and the mixture gently stirred to hasten the evaporation of the solvent. The coarse powder was then dried in a vacuum oven at $60^{\circ} \mathrm{C}$ for two

\footnotetext{
* Standard Oil Company of California.
}

hours. A convenient volume of 70 per cent acetone in water ( $v / v)$ was added and the mixture agitated for one minute in a Waring Blender to dissolve any lumps. To expel the air bubbles, the Celite was transferred to a beaker and warmed gently on a steam bath until bumping occurred. The slurry was then added to a chromatographic column filled with $\mathbf{7 0}$ per cent acetone by means of a large-bore dropping pipette. The Celite was uniformly packed by gravity by opening the column and allowing it to flow at a maximum rate. Air-free columns have been obtained by observing two precautions: a) the tip of the pipette by which the slurry is delivered should be placed below the meniscus of fluid at the top of the column before discharging the contents; b) the temperature of the water flowing through the jacket of the column should be the same as that of the slurry and the solvent systems (room temperature). A filter paper disc was placed on top of the Celite column and the column was then washed with $150 \mathrm{ml}$. of 55 per cent acetone before use.

b) The loading of fatty acids on the column (11). Ten to twenty-ml. samples of the total fatty acids of various lipide classes that were dissolved in petroleum ether and placed in volumetric flasks were removed and placed in a $50-\mathrm{ml}$. beaker. The solvent was evaporated off on a warm water bath under a stream of nitrogen. The residual fatty acids were then dissolved in $0.4 \mathrm{ml}$. of Standard White Oil and $15 \mathrm{ml}$. of anhydrous peroxidefree ether. Then $0.52 \mathrm{gram}$ of coated Celite was added. The beaker was placed in a tray of warm water, and with constant stirring under a stream of nitrogen, the ether was blown off. The thoroughly dried powdery mull was then added to the top of the chromatographic column with a spatula. The beaker was rinsed several times with several $\mathrm{ml}$. of warmed 55 per cent acetone and the washings were also added to the top of the column. The mull containing the acids was gently agitated with a glass rod and allowed to settle by gravity. Another filter paper disc was then placed on top of the mull.

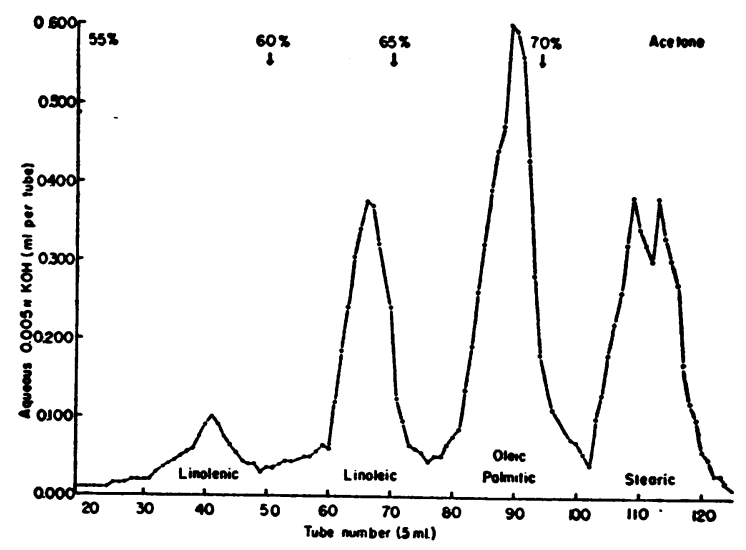

Fig. 3. Resolution of a Mixture of Linolenic, Linoleic, Palmitic, Oleic, and Stearic Actds

Note that palmitic and oleic acids come off the column together. 


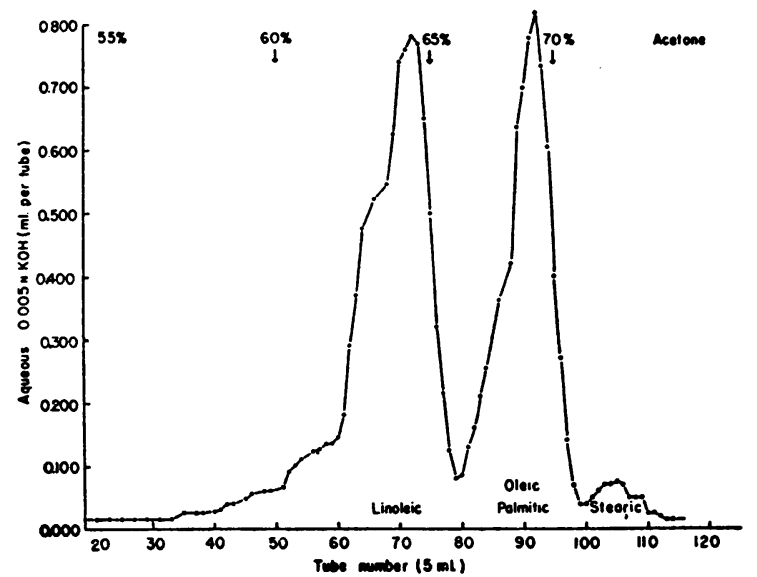

Fig. 4. The Chromatographic Separation of the Total Fatty Acids of Sterol Esters of the Plasma of Subject J

The solvent systems employed in sequence in the separation of known mixtures or plasma extracts containing the common higher fatty acids were as follows:

55 per cent acetone elutes arachidonic acid linolenic acid lauric acid

60 per cent acetone elutes linoleic acid myristic acid

65 per cent acetone elutes palmitic acid oleic acid ${ }^{5}$

70 per cent acetone elutes stearic acid

The systems were changed at intervals noted in Figures 2 to 6 . The capacity of the column for total fatty acids was approximately 60 milligrams. The columns may be used repeatedly ( 5 to 10 times) provided they are kept at a constant temperature. Under these conditions, elution was quantitative and the removal of individual fatty acids with predetermined volumes of the various solvent systems could be anticipated.

c) Collection and assay of samples. The columns were mounted on an automatic fraction collector adjusted to collect 5-ml. samples every three minutes. The samples were titrated under nitrogen with $0.005 \mathrm{~N} \mathrm{KOH}$ to a blue-green endpoint using bromthymol blue as an indicator. The contents of the tubes representing individual fatty acids were pooled, made acid with $6 \mathrm{~N} \mathrm{H}_{2} \mathrm{SO}_{4}$ and concentrated under nitrogen at reduced pressure. The fatty acids were then extracted with petroleum ether, washed, dried and assayed for content and radioactivity as previously described.

5 For weight measurements this fraction was subjected to the Bertram oxidation procedure (4) and then rechromatographed for the quantitative estimation of palmitic acid. The amount of oleic acid present in the original mixture was then obtained by subtracting the weight (by titration) of the recovered palmitic acid from that of the acids eluted by 65 per cent acetone during initial chromatography.
RESULTS

Nature and quantity of the fatty acids found in ester linkage with the various lipide complexes of the plasma

Typical examples of the resolving power of the silicic acid columns for the separation of the sterol esters and the triglycerides of the plasma using the solvent system recommended by Fillerup and Mead (3) are shown in Table I. In a series of quantitative experiments, recoveries of 95 per cent or more were constantly achieved for these fractions. Attempts at further fractionation of the lipide extract by this technique, however, were generally unsuccessful. Considerable cross contamination between "free fatty acids" "and sterols was noted. The gross overlapping of zones that occurred could not be obviated by either increasing the column length or altering the concentrations of the solvent systems employed in this investigation. Although the phospholipide fractions were generally eluted in a pure state by 25 per cent methanol in ether, the yields were frequently 10 to 20 per cent lower than those obtained by precipitation of the phospholipides in the cold by acetone and $\mathrm{MgCl}_{2}$. Losses appeared to be due primarily to the premature separation of small quantities of

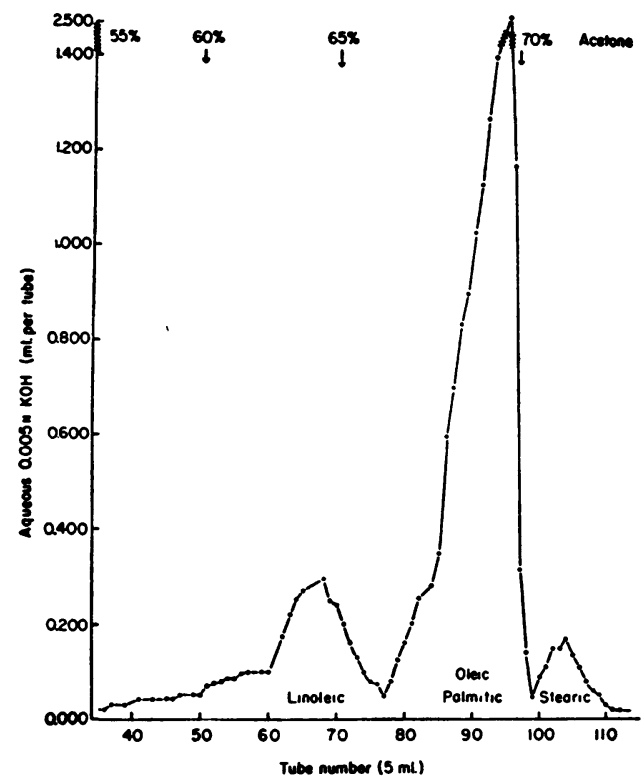

Fig. 5. The Chromatographic Separation of the Total Fatty Acids of the Triglycerides of the Plasma of Subject J

6 Added radioactive fatty acids. 
phospholipide when higher concentrations of diethyl ether were used in the elution of "free fatty acids" and sterols from the column.

The quantities of total fatty acids found in ester linkage with each of the major lipide complexes of the plasma are noted in Table II. These values compare favorably with those obtained by indirect measurements (12). The fatty acids of the triglycerides in the post-prandial plasma were usually present in the highest concentration, followed by the fatty acids of the phospholipides and then those of the sterol esters.

The results of the qualitative and quantitative resolution of known mixtures of some of the common straight-chain higher saturated and unsaturated fatty acids are depicted in Figures 2 and 3. Highly satisfactory separation of linolenic, linoleic, palmitic or oleic and stearic acids was accomplished by using kieselguhr column $1 \mathrm{~cm}$. in diameter and $120 \mathrm{~cm}$. in height. Preliminary experiments with shorter columns led to adequate resolution of palmitic and stearic acids. However, considerable overlapping was noted in the zones distinguishing linolenic from linoleic acid and linoleic from palmitic or oleic acid. As noted by previous investigators (4), the presence of each double bond some distance from the carboxyl group caused an acid to act like that of a saturated acid having a chain length of two less carbons. Thus, oleic, linoleic, and linolenic acids behave as and are indistinguishable from $\mathrm{C}_{16}, \mathrm{C}_{14}$, and $\mathrm{C}_{12}$ straightchain saturated acids, respectively. Similarly the $\mathrm{C}_{20}$ tetraene, arachidonic acid (an acid not avail-

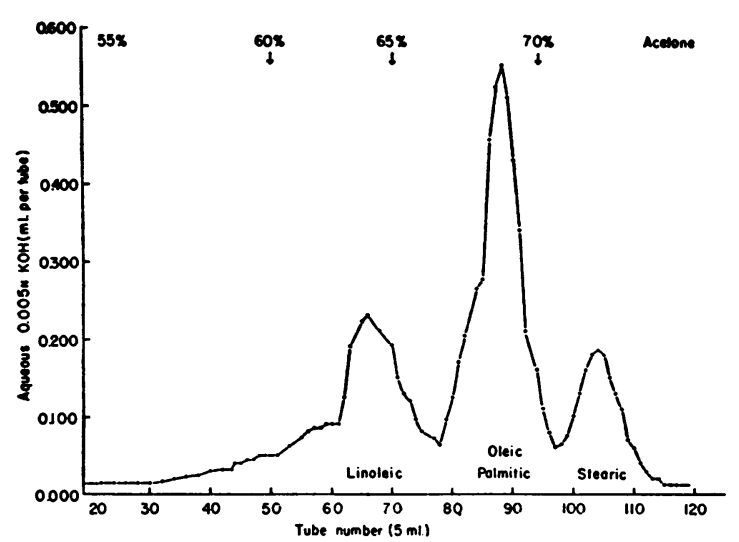

Fig. 6. The Chromatographic Separation of the Total Fatty Acids of the Phospholipides of the Plasma of Subject J
TABLE II

The total fatty acids of the sterol esters, phospholipides and triglycerides

\begin{tabular}{cccc}
\hline Subject & $\begin{array}{c}\text { Fatty acids } \\
\text { of sterol } \\
\text { esters }\end{array}$ & $\begin{array}{c}\text { Fatty acids } \\
\text { of phos- } \\
\text { pholipides }\end{array}$ & $\begin{array}{c}\text { Fatty acids } \\
\text { of tri- } \\
\text { glycerides }\end{array}$ \\
\hline & $m g . / 100 \mathrm{ml}$. & $m g . / 100 \mathrm{ml}$. & $m \mathrm{mg} / 100 \mathrm{ml}$. \\
$\mathrm{J}$ & 109 & 130 & 158 \\
$\mathrm{~S}$ & 90.7 & 118 & 119.5 \\
V & 73.9 & 102.6 & 98.1 \\
D & 94.1 & 134 & 138 \\
\hline
\end{tabular}

able in pure form at this time) is theoretically eluted in a manner akin to that of the $\mathrm{C}_{18}$ triene, linolenic acid (Figures 2 and 3 ) or the saturated $\mathrm{C}_{12}$ lauric acid.

The chromatographic separation of the fatty acids of the sterol esters, the triglycerides, and the phospholipides of the plasma is depicted in Figures 4,5 , and 6 . It is noted that the predominant components of all fractions are presumably linoleic, oleic, palmitic, and stearic acids. The various concentrations of the individual fatty acids associated with the major lipide complexes are listed in Table III. It should be stated that some titratable acidity, approximately two to four times that of the blank, occurred in the fractions eluted by 55 per cent acetone in water $(v / v)$. Although this may represent very small quantities of either lauric (13), linolenic and arachidonic acids (4), or the products of partial oxidation of some of the higher unsaturated acids, no definite "hill and valley" elution pattern was noted. The very small band that did form tended to spread widely. This was probably due to the high water content of the solvent system employed under these circumstances (4, 5 ). Since the small quantities of these acids that were recovered precluded further accurate chemical identification at this time, they have been excluded from the table. It is, therefore, apparent that the small amounts of the higher unsaturated acids of the plasma, as determined by the alkali isomerization technique (14), are not easily discernible by this method at this time.

From an analysis of Table III, it appears that oleic and palmitic acids, respectively, represent the major unsaturated and saturated fatty acids of the plasma of man. It is also noted that the fatty acids associated with the sterol esters are predominantly unsaturated-linoleic and oleic acids constituting approximately 86 per cent of the titratable acidity 
TABLE III

The distribution of the individual fatty acids associated with the major lipide complexes in the plasma of subject $J$ *

\begin{tabular}{|c|c|c|c|c|c|c|}
\hline & $\underset{\text { acid }}{\text { Linoleic }}$ & $\begin{array}{l}\text { Oleic } \\
\text { acid }\end{array}$ & $\begin{array}{l}\text { Stearic } \\
\text { acid }\end{array}$ & $\underset{\text { acid }}{\text { Palmitic }}$ & $\begin{array}{c}\text { Total } \\
\text { fatty acids } \\
\text { of major } \\
\text { complex }\end{array}$ & $\begin{array}{l}\text { Per cent recovery } \\
\text { of total fatty } \\
\text { acids added to } \\
\text { the column }\end{array}$ \\
\hline $\begin{array}{l}\text { Sterol esters } \\
\text { Triglycerides } \\
\text { Phospholipides }\end{array}$ & $\begin{array}{c}\text { mg. \% } \\
57.7 \\
18.9 \\
43.1\end{array}$ & $\begin{array}{c}\text { mg. \% } \\
31.9 \\
68.9 \\
31.2\end{array}$ & $\begin{array}{r}m g . \% \\
2.2 \\
7.3 \\
16.1\end{array}$ & $\begin{array}{c}m g . \% \\
11.5 \\
45.1 \\
23.1\end{array}$ & $\begin{array}{c}m g . \% \\
103.3 \\
140.2 \\
113.5\end{array}$ & 89 \\
\hline
\end{tabular}

Per cent distribution of the individual fatty acids recovered from the total fatty acid extract

$\begin{array}{llll}33.5 & 37.0 & 7.2 & 22.3\end{array}$

Per cent distribution of the individual fatty acids present in each major complex

$\begin{array}{lrrrr}\text { Sterol esters } & 55.8 & 30.9 & 2.2 & 11.1 \\ \text { Triglycerides } & 13.4 & 49.2 & 5.2 & 32.2 \\ \text { Phospholipides } & 37.9 & 27.5 & 14.1 & 20.5\end{array}$

* Obtained by analysis of the chromatographically separated fractions.

recovered from the kieselguhr column after the addition of this fraction. Similarly, 65 per cent of the titratable acidity associated with the phospholipides and 62 per cent of that found with the triglycerides were attributable to these unsaturated acids. Palmitic and stearic acids, on the other hand, were more widely distributed in the triglyceride and phospholipide complexes, with only small quantities noted in the sterol esters.

It is highly probable that both the composition and concentration of the individual fatty acids associated with each of the major lipide complexes vary considerably with the diet (15-17).

Incorporation of acetate-1-C $C^{14}$ into the total fatty acids of triglycerides, the sterol esters and the phospholipides (Figure 7, Table IV)

The appearance of radioactivity in the total fatty acids of the triglycerides following the administration of the $\mathrm{C}^{14}$-labelled two-carbon fragment was extremely rapid in all subjects. The specific activity of these substances invariably reached a maximum at two hours, declined sharply within a 24-hour period and then slowly declined during the next 72 hours. A semilogarithmic plot of the data demonstrates that decay does not occur by a single exponential process, and if additional points were taken over several more days the curves describing the decline of radioactivity probably could be resolved into a series of exponential rates. Thus, the calculation of a composite half-life for these fatty acids would not be very meaningful at this time. Undoubtedly a number of metabolic processes contribute to the disappearance of these materials from the blood stream (18).

The curve describing the specific activity of the fatty acids of the phospholipides increased more gradually to reach a plateau between 12 and 24 hours, at which point it intersected the specific activity curve of the fatty acids of the triglycerides and then fell off more slowly within the next 72

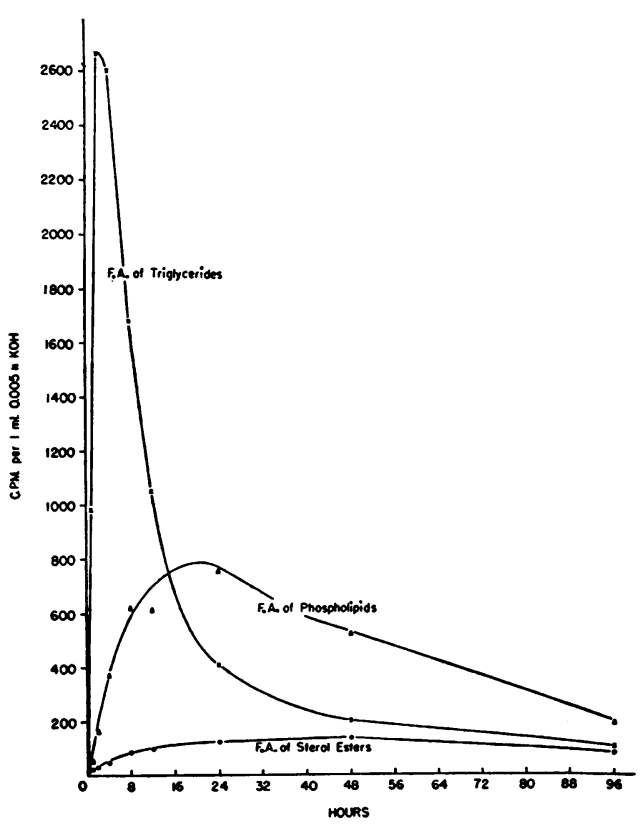

Fig. 7. The Incorporation of Acetate-1-C $C^{34}$ into the Total Fatty Acids of the Triglycerides, the Phospholipides, and the Sterol Esters of the Plasma of Subject J 
TABLE IV

Specific activity of the total fatty acids of the triglycerides, the sterol esters, and the phospholipides in the plasma

\begin{tabular}{|c|c|c|c|c|}
\hline Subject & $\begin{array}{c}\text { Time in } \\
\text { hours }\end{array}$ & $\begin{array}{l}\text { Fatty acids } \\
\text { of tri- } \\
\text { glycerides }\end{array}$ & $\begin{array}{l}\text { Fatty acids } \\
\text { of sterol } \\
\text { esters }\end{array}$ & $\begin{array}{l}\text { Fatty acids } \\
\text { of phos- } \\
\text { pholipides }\end{array}$ \\
\hline & & $\begin{array}{c}C P M / \\
0.005 \mathrm{mM}\end{array}$ & $\begin{array}{c}C P M / \\
0.005 \mathrm{mM}\end{array}$ & $\begin{array}{c}C P M / \\
0.005 \mathrm{mM}\end{array}$ \\
\hline $\mathrm{J}$ & $\begin{array}{r}1 \\
2 \\
4 \\
8 \\
12 \\
24 \\
48 \\
96\end{array}$ & $\begin{array}{r}984 \\
2,660 \\
2,600 \\
1,680 \\
1,050 \\
406 \\
202 \\
106\end{array}$ & $\begin{array}{r}20 \\
29 \\
48 \\
80 \\
96 \\
120 \\
126 \\
81\end{array}$ & $\begin{array}{r}61 \\
170 \\
378 \\
628 \\
320 \\
766 \\
532 \\
202\end{array}$ \\
\hline V & $\begin{array}{r}1 \\
2 \\
4 \\
8 \\
12 \\
24 \\
48 \\
96\end{array}$ & $\begin{array}{r}1,840 \\
5,705 \\
4,631 \\
3,689 \\
1,905 \\
729 \\
387 \\
187\end{array}$ & $\begin{array}{r}25 \\
41 \\
74 \\
110 \\
122 \\
151 \\
178 \\
103\end{array}$ & $\begin{array}{r}100 \\
251 \\
561 \\
933 \\
960 \\
1,280 \\
770 \\
320\end{array}$ \\
\hline $\mathbf{S}$ & $\begin{array}{r}1 \\
2 \\
4 \\
8 \\
12 \\
24 \\
48 \\
96\end{array}$ & $\begin{array}{r}2,025 \\
8,381 \\
5,267 \\
3,761 \\
2,470 \\
1,386 \\
540 \\
190\end{array}$ & $\begin{array}{l}10 \\
16 \\
25 \\
42 \\
45 \\
63 \\
69 \\
40\end{array}$ & $\begin{array}{r}51 \\
130 \\
270 \\
473 \\
627 \\
472 \\
395 \\
165\end{array}$ \\
\hline D & $\begin{array}{r}1 \\
2 \\
4 \\
8 \\
12 \\
24 \\
48 \\
96\end{array}$ & $\begin{array}{r}1,300 \\
3,625 \\
3,481 \\
2,733 \\
1,375 \\
560 \\
302 \\
140\end{array}$ & $\begin{array}{r}27 \\
60 \\
90 \\
152 \\
191 \\
226 \\
252 \\
140\end{array}$ & $\begin{array}{r}30 \\
80 \\
146 \\
322 \\
397 \\
332 \\
260 \\
110\end{array}$ \\
\hline
\end{tabular}

* Counts per minute per 0.005 millimole.

hours. When plotted semilogarithmically the decay curve extending from 24 to 96 hours declined exponentially and the half-life of this fraction was approximately 50 to 60 hours. On the other hand, the synthesis of labelled fatty acids entering into ester linkages with the sterols of the plasma increased very slowly during the first 48 hours, at which point it reached its maximum and then fell very slowly. At no time did the specific activity of the fatty acids of sterol esters exceed that of the triglyceride or phospholipide fatty acids. At the height of incorporation of $\mathrm{C}^{14}$ into the total fatty acids of the major lipide complexes, the specific activity of the fatty acids of the triglycerides was two to four times that of the phospholipides and more than twenty times that of the fatty acids of sterol esters.
Incorporation of acetate-1-C $\mathrm{C}^{14}$ into certain of the chromatographically separated fatty acids of the triglycerides, phospholipides and sterol esters ( Table $V$ )

The incorporation of radioactivity into certain of the individual fatty acids of the various lipide complexes followed more or less the same general pattern noted in the formation of the total fatty acids of each group. Thus, the specific activity of the palmitic, stearic, and oleic acids found in ester linkage with the triglycerides was maximum two to four hours after the administration of the acetate. Despite the difference in concentrations of these fatty acids in the plasma, palmitic acid showed the greatest specific activity at its peak, with less activity in stearic, and still less in oleic acid.

The presence of radioactivity in the fraction eluted by 60 per cent aqueous acetone (4) is probably due to contamination of the linoleic acid by the

\section{TABLE V}

Specific activity* of the chromatographically isolated fatty acids of the triglycerides, the sterol esters, and the phospholipides in the plasma of subject $J$

\begin{tabular}{|c|c|c|c|c|c|}
\hline & $\begin{array}{c}\text { Time } \\
\text { in } \\
\text { hours }\end{array}$ & $\begin{array}{l}\text { Palmitic } \\
\text { acid }\end{array}$ & $\begin{array}{l}\text { Stearic } \\
\text { acid }\end{array}$ & $\begin{array}{l}\text { Oleic } \\
\text { acid }\end{array}$ & $\begin{array}{c}\text { Linoleict } \\
\text { and } \\
\text { Myristic } \\
\text { acid }\end{array}$ \\
\hline \multirow[t]{2}{*}{ Triglycerides } & $\begin{array}{l}1 \\
2 \\
4 \\
8\end{array}$ & $\begin{array}{l}1,953 \\
5,409 \\
5,115\end{array}$ & $\begin{array}{r}618 \\
2,433 \\
3,024 \\
\end{array}$ & $\begin{array}{r}294 \\
1,497 \\
1,263\end{array}$ & $\begin{array}{l}474 \\
906 \\
627 \\
\end{array}$ \\
\hline & $\begin{array}{l}12 \\
24 \\
48 \\
96\end{array}$ & $\begin{array}{r}2,910 \\
663 \\
402 \\
171\end{array}$ & $\begin{array}{r}1,929 \\
552 \\
243 \\
96\end{array}$ & $\begin{array}{r}267 \\
252 \\
96 \\
81\end{array}$ & $\begin{array}{r}222 \\
105 \\
51 \\
-\end{array}$ \\
\hline Sterol Esters & $\begin{array}{r}1 \\
2 \\
4 \\
8 \\
12\end{array}$ & $\begin{array}{r}96 \\
120 \\
171 \\
282 \\
375\end{array}$ & & $\begin{array}{r}30 \\
45 \\
72 \\
105 \\
156\end{array}$ & NSC \\
\hline & $\begin{array}{l}48 \\
96\end{array}$ & $\begin{array}{l}495 \\
351\end{array}$ & & $\begin{array}{l}201 \\
120\end{array}$ & $\cdot$ \\
\hline Phospholipides & $\begin{array}{r}1 \\
2 \\
4 \\
8 \\
12 \\
24 \\
48 \\
96\end{array}$ & $\begin{array}{r}183 \\
432 \\
942 \\
1,563 \\
1,578 \\
1,890 \\
1,287 \\
-\end{array}$ & $\begin{array}{r}72 \\
210 \\
465 \\
723 \\
672 \\
1,110 \\
804 \\
-\end{array}$ & $\begin{array}{r}63 \\
159 \\
297 \\
534 \\
555 \\
825 \\
414 \\
-\end{array}$ & \\
\hline
\end{tabular}

* Counts per minute per 0.005 millimole.

$\dagger$ Radioactivity in this fraction is presumably due to presence of small quantity of myristic acid (see Results). $\ddagger$ No significant counts above background. 
very small quantity of myristic acid thought to be present in the plasma of man (13), which is also eluted from the chromatographic column by this solvent system. If this be the case, the myristic acid fraction would undoubtedly be diluted by the presence of presumably unlabelled linoleic acid (19-22). The specific activity of the myristic acid would therefore be greater than that stated, since the total acidity of the combined fraction was used in the calculation. This fraction was not subjected to the Bertram oxidation procedure (4) for the separation of the saturated from unsaturated acids because of difficulties encountered in handling very small quantities of saturated acids by this method, as would be the case with myristic acid in this particular instance.

The curves describing the appearance of $\mathrm{C}^{\mathbf{1 4}}$ in the palmitic, stearic, and oleic acids attached to the phospholipides closely resemble those of the total fatty acids of this fraction. The maximum specific activity was again attained approximately 24 hours after the introduction of the precursor. The relative distribution of counts within the individual fatty acids was somewhat similar to that noted in the triglyceride fractions. No significant radioactivity was found, however, in that fraction containing linoleic acid and possibly traces of myristic acid.

The relatively small amount of radiactivity noted in the fatty acids of the sterol esters was predominantly due to the presence of labelled palmitic and oleic acids. Although some labelling occurred, the quantities of stearic acid isolated from this complex were too small for accurate analyses for specific activity. Again there was no discernible radioactivity in the relatively large quantity of linoleic acid that was isolated.

\section{DISCUSSION}

It is known that the fatty acids entering into ester linkage with each of the specific major lipide complexes are mixtures which may vary in quantity and composition. In contrast to the triglycerides, the fatty acids of the cholesterol esters under normal circumstances contain large quantities of linoleic acid. It has been shown that this polyunsaturated acid is not readily synthesized by the mammalian organism (19-22) and is presumably derived in toto from the diet. The spe- cific activity of the saturated and monoethenoid fatty acids of the "non-phospholipide" fraction in this and other studies $(16,18,23,24)$ would tend to be greater if the contribution derived from the large unlabelled linoleic acid fraction of the sterol esters and from the somewhat smaller fraction from the triglycerides was excluded from the calculations. Similarly, other polyunsaturated fatty acids such as linolenic and arachidonic acids thought to reside in the phospholipide and sterol ester complexes (25) would also tend to alter the estimation of the specific activity of these fractions. The degree to which this occurs, however, would depend upon certain characteristics of some of the polyethenoid acids. Although relatively little is known about the intermediary metabolism of the higher unsaturated fatty acids, it has been shown in animals that some of the processes leading to the formation of one essential fatty acid from another may involve endogenous synthesis. Thus, Widmer and Holman (21) noted that fat-starved rats apparently synthesized arachidonic acid from linoleic, but not from linolenic acid. Further investigation of the problem by Mead, Steinberg, Howton, and Slaton $(20,22)$ demonstrated the formation of arachidonic acid from an exogenous precursor presumably derived from linoleic acid by the addition of a two-carbon fragment obtained from administered radioactive acetate. It is, therefore, apparent that the variation between the actual and theoretical specific activities of the total fatty acids, particularly of the phospholipide and sterol ester fractions, would also be dependent upon the extent to which labelled acetyl coenzyme A is utilized to form tetraenes and conceivably other highly unsaturated acids that may exist in small quantities in the plasma of man. Because of difficulties inherent in the isolation of these acids in the pure state, the specific activities listed in this study are only relative.

The curves (Figure 7) depicting the synthesis of the labelled fatty acids of the triglycerides (A) and the phospholipides (B) resemble that of a time course curve demonstrating the relationship between a precursor (A) and product (B) when a labelled precursor (acetate) is furnished at zero time (24). Since it has been implied on the basis of experiments in animals $(23,26)$ as well as man (18) that the triglyceride fraction is apparently the major vehicle for the transport of fatty acids in 
the plasma, it seems likely that at least certain of the individual fatty acids of the phospholipides such as palmitic, stearic, and oleic acids are derived in part from or are exchanging with the fatty acids of the triglycerides. The same reasoning may apply to a limited extent to the fatty acids of the sterol esters. However, the lack of adequate studies concerning the relative rates of synthesis of this fraction in the mammalian liver and its presence in other tissues precludes further speculation on this point.

Some information concerning the interconversion of fatty acids may be derived from an analysis of the relative specific activities of the individual acids. It may be noted that despite the different concentrations of these substances in the plasma, the turnover rates of palmitic, stearic, and oleic acids within a major lipide complex are approximately comparable. Furthermore, the greatest degree of radioactivity was found in the palmitic acid fraction of each group, followed then by stearic and oleic acids. It would appear, from the work of Dauben, Hoerger, and Peterson (27), that palmitic acid for the most part is synthesized directly from two-carbon units and the amount derived from the process of elongation of an intermediate fatty acid such as myristic by the addition of a two-carbon fragment is exceedingly small. On the other hand, Stetten and Schoenheimer (28) and Zabin (29) have indicated that a significant quantity of stearic acid is formed by direct elongation of the carbon chain of palmitic acid by two-carbon atoms. Furthermore, the formation of the monounsaturated oleic acid probably occurs in a manner similar to that of the saturated acids. Indeed, Anker (30) studied the relative distribution of the isotope in the various higher fatty acids after feeding myristic acid-1-C $\mathrm{C}^{14}$ to rats and concluded that the 14 carbon atoms of myristic acid were utilized for carbon atoms 5 to 18 of oleic acid by way of palmitic and stearic acids. A similar investigation employing acetate-1- $\mathrm{C}^{14}$ by Dauben, Hoerger, and Peterson (27) gave support to this postulate by showing that the pattern of distribution of the isotope in the degraded unsaturated $\mathrm{C}_{18}$ acids was identical with that of the saturated acids. Additional information on the metabolic interrelationships of these acids was provided by Weinman, Chaikoff, Dauben, Gee, and Entenman (31) who found that when pal- mitic acid was catabolized in vivo, it was primarily converted to small carbon units without any appreciable formation of acids of intermediary carbon length. In contrast, the catabolism of stearic acid (32), while similarly breaking down to short chain units, also gave rise to an appreciable quantity of palmitic acid. The relative concentration of $\mathrm{C}^{14}$ in the palmitic, stearic, and oleic acid fractions isolated in this study would tend to support the occurrence of these overall reactions in man. Thus, it can be assumed that palmitic acid is the major higher saturated fatty acid intermediate formed from acetate. At least three pathways seem to be involved in the further metabolism of this acid. First, some palmitic acid is undoubtedly deposited in the fat depots as such. Second, a quantity is utilized as fuel by breaking down to two-carbon fragments which can enter the tricarboxylic acid cycle and provide a source of energy. Lastly, a portion of the palmitic acid pool is converted to stearic acid. Only small quantities of this $C_{18}$ acid are found in the plasma of man under normal circumstances. Presumably much of this acid is either oxidized for energy, desaturated to form oleic acid or reconverted to palmitic acid.

The absence of appreciable radioactivity in the linoleic acid fraction of the major lipide complexes of the plasma lends support to the contention that this diene cannot be detectably synthesized by the mammalian liver $(19,20,22,28)$. However, it has been shown recently by Mead, Slaton, and Decker (33) that at least the carboxyl carbon of linoleic acid can be utilized to a limited extent in the formation of some of the higher saturated fatty acids in the rat. The metabolic pathway involved in this reaction is not clear at this time. It may be mediated via a higher unsaturated acid such as arachidonic which can be formed from a linoleate derivative $(20,22)$ by the addition of a two-carbon fragment or by the direct conversion of linoleic acid to short chain or more intermediate units which then can be partially utilized in the synthesis of the saturated acids. This latter concept seems to be the more likely possibility.

\section{SUMMARY}

Certain specific saturated and unsaturated fatty acids associated with the major lipide complexes 
of the plasma of man were isolated and measured by chromatographic methods. The predominant fatty acid components of the sterol esters, the phospholipides, and the triglycerides were linoleic, oleic, palmitic, and stearic acids. The largest quantity of unsaturated acids was noted in the sterol ester fraction. The majority of the saturated fatty acids were present in the triglycerides. The rates of synthesis of the total and certain of these individual higher fatty acids of man following the administration of acetate-1- $\mathrm{C}^{14}$ were also studied. Some of the fatty acids of the phospholipides appeared to be derived in part from those of the triglycerides. The triglycerides probably represent the major vehicle for the transport of fatty acids in man as well as animals. The highest concentrations of radioactivity appeared in the palmitic acid fraction of each of the major lipide complexes, followed by those in the stearic and oleic acids. The absence of demonstrable activity in the isolated linoleic fractions signified the lack of endogenous formation of this polyunsaturated fatty acid in man.

\section{REFERENCES}

1. Borgström, B., Investigation on lipid separation methods. Separation of phospholipids from neutral fat and fatty acids. Acta physiol. Scandinav., 1952, 25, 101.

2. Borgström, B., Investigation of lipid separation methods. Separation of cholesterol esters, glycerides and free fatty acids. Acta physiol. Scandinav., 1952, 25, 111.

3. Fillerup, D. L., and Mead, J. F., Chromatographic separation of the plasma lipids. Proc. Soc. Exper. Biol. \& Med., 1953, 83, 574.

4. Crombie, W. M. L., Comber, R., and Boatman, S. G., The estimation of unsaturated fatty acids by reversed-phase partition chromatography. Biochem. J., 1955, 59, 309.

5. Howard, G. A., and Martin, A. J. P., The separation of the $\mathrm{C}_{12}-\mathrm{C}_{18}$ fatty acids by reversed-phase partition chromatography. Biochem. J., 1950, 46, 532.

6. Delsal, J.-L., Nouveau procédé d'extraction des lipides du sérum par la méthylal. Applications aux microdosages du cholestérol total, des phosphoaminolipides et des protéides. Bull. Soc. chim. biol., 1944, 26, 99.

7. Kritchevsky, D., McCandless, R. F. J., Knoll, J. E., and Eidinoff, M. L., Triolein- $\mathrm{H}^{3}$. J. Am. Chem. Soc., 1955, 77, 6655.

8. Borgström, B., On the mechanism of the intestinal fat absorption. III. Metabolism of lipids 4. Acta physiol. Scandinav., 1952, 25, 140.
9. Mead, J. F., and Fillerup, D. L., Plasma lipids in fat deficiency. Proc. Soc. Exper. Biol. \& Med., 1954, 86, 449.

10. Hayes, F. N., Ott, D. G., and Kerr, V. N., Liquid scintillators. II. Pulse-height comparison of secondary solutes. Nucleonics, 1956, 14, 42.

11. Silk, M. H., and Hahn, H. H., The resolution of mixtures of $\mathrm{C}_{10}-\mathrm{C}_{24}$ normal-chain fatty acids by reversed-phase partition chromatography. Biochem. J., 1954, 56, 406.

12. Peters, J. P., and Van Slyke, D. D., Quantitative Clinical Chemistry. Interpretations. 2nd ed., Baltimore, The Williams \& Wilkins Co., 1946, vol. 1, p. 469.

13. Van de Kamer, J. H., Pikaar, N. A., BolssensFrankena, A., Couvée-Ploeg, C., and Van Ginkel, L., Quantitative determination of the different higher saturated fatty acids in fat from blood, chyle and faeces, by means of partition chromatography on rubber. Biochem. J., 1955, 61, 180.

14. Evans, J. D., Waldron, J. M., Oleksyshyn, N. L., and Riemenschneider, R. W., Polyunsaturated fatty acids in normal human blood. J. Biol. Chem., 1956, 218, 255.

15. Stevens, B. P., and Chaikoff, I. L., Incorporation of short chain fatty acids into phospholipides by the rat. J. Biol. Chem., 1951, 193, 465.

16. Anderson, W. E., and Mendel, L. B., The relation of diet to the quality of fat produced in the animal body. J. Biol. Chem., 1928, 76, 729.

17. Sinclair, R. G., The metabolism of the phospholipids. VII. Further evidence of the selection and retention of unsaturated fatty acids by phospholipids of animal tissues. J. Biol. Chem., 1935, 111, 275.

18. Lipsky, S. R., McGuire, J. S., Jr., Bondy, P. K., and Man, E. B., The rates of synthesis and the transport of plasma fatty acid fractions in man. J. Clin. Invest., 1955, 34, 1760.

19. Bernhard, K., and Schoenheimer, R., The inertia of highly unsaturated fatty acids in the animal, investigated with deuterium. J. Biol. Chem., 1940, 133, 707.

20. Mead, J. F., Steinberg, G., and Howton, D. R., Metabolism of essential fatty acids. Incorporation of acetate into arachidonic acid. J. Biol. Chem., 1953, 205, 683.

21. Widmer, C., Jr., and Holman, R. T., Polyethenoid fatty acid metabolism. II. Deposition of polyunsaturated fatty acids in fat-deficient rats upon single fatty acid supplementation. Arch. Biochem., $1950,25,1$.

22. Steinberg, G., Slaton, W. H., Jr., Howton, D. R., and Mead, J. F., Metabolism of essential fatty acids. IV. Incorporation of linoleate into arachidonic acid. J. Biol. Chem., 1956, 220, 257.

23. Pihl, A., and Block, K., The relative rates of metabolism of neutral fat and phospholipides in various tissues of the rat. J. Biol. Chem., 1950, 183, 431. 
24. Reiner, J. M., The study of metabolic turnover rates by means of isotopic tracers. II. Turnover in a simple reaction system. Arch. Biochem. \& Biophys., 1953, 46, 80.

25. Achaya, K. T., Alfin-Slater, R. B., and Deuel, H. J., Nature of fatty acids in liver lipid fractions of the rat. Federation Proc., 1955, 14, 170.

26. Bloom, B., Chaikoff, I. L., Reinhardt, W. O., and Dauben, W. G., Participation of phospholipides in lymphatic transport of absorbed fatty acids. J. Biol. Chem., 1951, 189, 261.

27. Dauben, W. G., Hoerger, E., and Peterson, J. W., Distribution of acetic acid carbon in high fatty acids synthesized from acetic acid by the intact mouse. J. Am. Chem. Soc., 1953, 75, 2347.

28. Stetten, D., Jr., and Schoenheimer, R., The conversion of palmitic acid into stearic and palmitoleic acid in rats. J. Biol. Chem., 1940, 133, 329.
29. Zabin, I., On the conversion of palmitic acid to stearic acid in animal tissues. J. Biol. Chem., 1951, 189, 355.

30. Anker, H. S., On the mechanism of fatty acid synthesis in vivo. J. Biol. Chem., 1952, 194, 177.

31. Weinman, E. O., Chaikoff, I. L., Dauben, W. G., Gee, M., and Entenman, C., Relative rates of conversion of the various carbon atoms of palmitic acid to carbon dioxide by the intact rat. J. Biol. Chem., 1950, 184, 735.

32. Weinman, E. O., Chaikoff, I. L., Stevens, B. P., and Dauben, W. G., Conversion of first and sixth carbons of stearic acid to carbon dioxide by rats. J. Biol. Chem., 1951, 191, 523.

33. Mead, J. F., Slaton, W. H., Jr., and Decker, A. B., Metabolism of the essential fatty acids. II. The metabolism of stearate, oleate, and linoleate by fatdeficient and normal mice. J. Biol. Chem., 1956, 218, 401.

\section{SPECIAL NOTICE TO SUBSCRIBERS}

Post Offices will no longer forward the Journal when you move.

Please notify The Journal of Clinical Investigation, Business Office, 622 West 168th Street, New York 32, N. Y. at once when you have a change of address, and do not omit the zone number if there is one. 